InOedia $\quad \begin{aligned} & \text { InMedia } \\ & \text { The French Journal of Media Studies }\end{aligned}$

3 | 2013

Cinema and Marketing

\title{
(Re)defining Visual Studies
}

\section{François Brunet}

\section{(2) OpenEdition \\ Journals}

Electronic version

URL: http://journals.openedition.org/inmedia/543

DOI: 10.4000/inmedia.543

ISSN: 2259-4728

\section{Publisher}

Center for Research on the English-Speaking World (CREW)

\section{Electronic reference}

François Brunet, " (Re)defining Visual Studies », InMedia [Online], 3 | 2013, Online since 23 April 2013 connection on 08 September 2020. URL : http://journals.openedition.org/inmedia/543 ; DOI : https:// doi.org/10.4000/inmedia.543

This text was automatically generated on 8 September 2020

(c) InMedia 


\title{
(Re)defining Visual Studies
}

\author{
François Brunet
}

1 This review is necessarily fragmentary, considering the tremendous publishing output associated with the label "visual studies," the continuing re-definition of this field, and the fact that I am writing from a doubly external vantage point, since my own research is in the history of images and since I am writing in the French context, where visual studies remains a shadowy presence at best.

2 I am indebted to James Elkins's introductory remarks to his recently edited volume, Theorizing Visual Studies: Writing Through the Discipline (Routledge, 2012), based on the prolonged group work of graduate students from the University of Chicago and other institutions. This volume, organized as a repertory of thematic entries (for the letter A : Airborne Horses, Anaesthetics, Animal, Animations, Arial, Ars Oblivionalis, Artifact, Augmented Reality) demonstrates the lasting influence of the "picture theory" outlined by W.J.T. Mitchell in his 1994 book by that title (Picture Theory, Essays on Verbal and Visual Representation, Chicago, 1994), with its seminal claims of a "pictorial turn" in contemporary culture and the need to raise "visual literacy," i.e. a new competence in understanding or approaching images, their presence, their "magic"- away especially from the dominance of linguistic models of interpretation, and towards a "picture theory" in which specific pictures are invoked as autonomous agents of conceptualization. The alphabetical organization of this volume, functioning as a denial of any overarching epistemology, testifies also to the continuing relevance of Mitchell's definition of visual studies as a "de-disciplinary exercise" and its link to the ongoing reconfiguration, on certain American campuses, of disciplinary maps as well as faculty/ student divisions of labor. Along with other texts such as Margaret Dikovitskaya's archeology of the field (Visual Culture: The Study of the Visual after the Cultural Turn, MIT Press, 2006) and Keith Moxey's landmark article on the concurrence of parallel and separate English- and German-language visual studies ("Visual Studies and the Iconic Turn," Journal of Visual Culture, $7: 2$, August 2008, 131-146), this volume, and particularly James Elkins's introductory essays, usefully highlight the continuing need to define a field that has constantly resisted definition. 
3 It must be recalled, first of all, that in the USA the "field" of visual studies emerged primarily, in the 1990s, as a teaching initiative, most frequently taking the form of interdisciplinary or inter-departmental programs aimed at undergraduate students with concentrations in art history, film and media studies, in the humanities, or even in general courses offered across the board. The continuing dominance of a pedagogical approach to visual studies, as a kind of "propedeutics" to contemporary (visual) culture, accounts for the proliferation of textbooks and readers. At least two popular textbooks have already undergone second editions : Nicholas Mirzoeff's Introduction to Visual Culture (Routledge, 2000/2008) and Marika Sturken's and Lisa Cartwright's Practices of Looking : An Introduction to Visual Culture (Oxford, 2001/2009).

This didactic approach has often gone hand in hand with the "de-disciplinary" outlook proposed by Mitchell and since adopted by many proponents of visual studies. Teaching visual culture has often been akin to deconstructing established disciplinary boundaries, generic hierarchies, arguably even the discursive preeminence of faculties in determining the course of the field. This claim was most commonly interpreted and debated, in the context of the 1990s, as a strategy of undoing high/low distinctions, beginning with the art historical canon, in favor of a generalized, equalizing history of images. Hence, since the early 2000s, the recurring objection that visual studies amounted to "everything studies" (John Davis) and James Elkins's demand, in his Visual Studies: A Skeptical Introduction (Routledge, 2003), for a more rigorous epistemology of visual studies - or, as he put it, for a search for "ways to make it harder to write essays on Benetton, Calvin Klein, Bakelite, Barbie, Burning Man, contemporary curiosity cabinets, snow globes, the history of buoys," etc. As shown by Elkins's more recent interventions (notably in a 2011 seminar entitled "A Farewell to Visual Studies"), the quest for "ways to make visual studies more difficult," i.e. especially more theoretically demanding or coherent, goes on today. This renewed quest would seem, for Elkins, to entail a "farewell," if not to visual studies, at least to the political critique of images and their uses that has occupied much of the pedagogical and editorial terrain since the late 1990s.

5 This political critique of images, often presented as the field's most salient aspect, derives from the two intellectual traditions that nourished the early work of its principal American pioneer, Tom Mitchell (particularly Iconology. Image, Text, Ideology, 1986) : French poststructuralist theory and British cultural studies (Raymond Williams, Frederic Jameson, Stuart Hall). This political dimension has also reflected, both in the USA and the UK, the urgency of the culture wars and the "resistance" of academia against the neo-conservative agenda. It has been embodied most conspicuously in Mirzoeff's Introduction to Visual Culture, ambitiously reworked in his recent The Right to Look: A Counterhistory of Visuality (Duke, 2011). This approach claims, against the iconological and semiological traditions, the diversity and inequality of viewers in front of images as a primary and not an auxiliary criterion of their "meaning" or rather their historical functions. It undertakes the study and teaching of visual culture as a way of decoding power structures or "gazes" (colonial, sexual, economic, disciplinary) lodged in visual transactions.

6 The most obvious consequence of this political critique of images is the durable deconstruction of art-historical canons. Today, the practice of art history in the English-language world (and beyond) is deeply impregnated with non-canonical and non-ethnocentric objects as well as the political functions and currents of art. 
Conversely, in a reflection of the genealogical linkage of visual studies to art history, much work in visual studies continues, as Elkins notes, to pay excessive attention to subversive re-contextualizations of "high" or "art" objects rather than to more vernacular imageries and the less visible social and media-based economies of their circulation. More pointedly, the political brand of visual studies has, in the 2000s and particularly in the wake of $9 / 11$ and the "war on terror", paid increasing attention to "image wars", practices of iconoclasm or "iconoclash" (Bruno Latour and Peter Weibel, Iconoclash, Beyond the Image-Wars in Science, Religion and Art, MIT, 2002) and, more broadly, to the interactions of visual cultures and religions. W.J.T. Mitchell has recently turned picture theory into a radical, but more general, political commentary of the Bush era in its confrontations with the twin "enemies" of cloning and terrorism (Cloning Terror, The War of Images from 9/11 to the Present, Chicago, 2011) while reorienting his archeology of the media of image and text towards a critique of race itself as a (visual) medium (Seeing through Race, Harvard, 2012). In spite of some predictions, the election and reelection of Barack Obama have not, so far, resulted in a decline of such approaches, nor of the larger dynamics of the culture wars. On the contrary, the undeniable appeal of political critiques of visuality to new generations of students, especially in Europe, seems to destine them to continued growth.

The "alternative" trend of visual studies, sometimes called "new visual studies", is therefore not to be understood as a successor to the first. It stands in contrast to the "indiscipline" of visual culture in that it signals a new academic attempt at interdisciplinary investigation of images and their uses, especially in research, across the spectrum of scientific fields. In ways that are sometimes reminiscent of initiatives of the 1980s, this trend involves, among other aspects, observations on interactions, in the digital era, between artistic and scientific imageries; explorations of the cognitive dimensions of imaging technologies and virtual environments ; inquiries into tagging and indexing methodologies. One point often made in support of such a return to (inter-) disciplinary approaches is, paradoxically, that the political critique has often kept student attention focused on culturally-sanctioned objects (whether "high" or "low") and more particularly to the institutional realm of art. "New visual studies" thus seek to broaden the terrain, so as to encompass not only social spaces and social practices of seeing, being seen, looking at and being looked at, but various human and technical components of vision and visibility (from perceptions of color, volume, movement, aging, etc., to experiments in augmented reality, tactile technologies, MRI imagery, etc.).

In some ways, then, this trend might be seen as a neo-disciplinary and de-politicizing one, except that it shares with the former a continuing emphasis on the phenomenological approach of images and their presence, construed, as Keith Moxey points out, as an "ontological demand" and a methodological alternative to the prepictorial-turn emphasis on "meaning". "Works of art, writes Moxey, are objects now more appropriately encountered than interpreted" ("Visual Studies and the Iconic Turn," 132). James Elkins's repeated call to unleash a true "picture theory", i.e. to deploy effectively the theoretical powers of images (instead of continuing to use them, in academic texts, as "illustrations" or "mnemonic" tools) remains something of an elusive quest today ; but it links the current trend to Mitchell's founding genealogy, in Iconology, of the image as a theoretical byproduct of, and alternative to, Western logocentrism. 
9 Meanwhile, Keith Moxey's article is one of the first serious attempts, in the Englishspeaking academic world, to take account of a parallel German-language school of visual studies, or Bildwissenchaft, influential in Eastern and Northern Europe and known especially through the work of Hans Belting and Horst Bredekamp. This trend is traced to the work of Gottfried Boehm (Was ist ein Bild, Fink,1995) and his notion of an "iconic turn," coined almost exactly at the same time as Mitchell's "pictorial turn," and sharing with the latter an emphasis on the presence, magic, and animistic "powers" of images in contemporary culture, and a reticence to interpret such iconic vitality in linguistically-based categories, but differing from Mitchell's "picture theory" in its reliance on anthropology and the philosophy of language. As Moxey points out, this "German" school is more mindful than the English-language political tradition of both the general, anthropological "iconic" property of images to refer to realities and the technological and communicational specificities of particular media. Horst Bredekamp's recent exploration of "picture acts" (Theorie des Bildakts, Suhrkamp Verlag, 2010) appears as the current culmination of this school, in proposing an anthropological and language-philosophy-based analysis of the "power of images," a theme previously treated in a more politically-oriented direction by W.J.T. Mitchell in What Do Pictures Want? (Chicago, 2006). The increasing dialogue of the German- and English-language schools of visual studies is a promise for the future and, in view of growing interest in the field in Europe, a possible chance for wider exposition in France.

\section{AUTHOR}

\section{FRANÇOIS BRUNET}

Université Paris Diderot-Paris 7 